\title{
Comparing Responsibilities between Outreach and Staff Secondary School Athletic Trainers
}

\author{
Trisha Brown", Ronald James Ting, Vanessa Fiaud
}

\author{
Department of Sports and Exercise Science, West Texas A\&M University, Canyon, Texas 79015, USA
}

Received Date: May 19, 2021; Accepted Date: June 07, 2021; Published Date: June 21, 2021

"Corresponding author: Trisha Brown, Department of Sports and Exercise Science, West Texas A\&M University, Canyon, Texas 79015, USA. Tel: +1 (806) 651-3647; Email: tmbrown@wtamu.edu

\section{Abstract}

Context: Athletic trainers working in the secondary school setting is work can be hired through the institutions themselves or outreach through various clinics. Recently, researchers have found discrepancies in the job descriptions for athletic trainers can affect their ability to perform their necessary duties.

Objective: To compare the differences in duties, job descriptions, and satisfaction between athletic trainers employed in the secondary school setting through outreach contracts and those employed by the schools or districts.

Design: Cross-sectional study.

Setting: Web-based online survey.

Patient or Other Participants: A total of 82 individuals answered the survey, 68 of which identified themselves as certified athletic trainers working in the secondary school setting.

Results: Many athletic trainers who had similar expectations in their hours or job descriptions to their actual duties had higher job satisfaction than those who did not. There was no difference found between athletic trainers who were outreach and those who were staff athletic trainers.

Conclusions: Accuracy of job descriptions and expectations had positive job satisfaction. We believe that if athletic trainers are given appropriate job descriptions and expectations concerning their roles on campus, they will be better equipped to perform as needed.

Keywords: Secondary School Athletic Trainers, Satisfaction, Job Description

\section{Key Points:}

- Athletic trainers are typically hired in the secondary school through two ways, staff and outreach.

- Through this difference, previous research has found discrepancies in athletic trainers' job description, causing difficulties in their ability to perform and their satisfaction.

- When expectations and job descriptions accurately capture the actual duties and role of the athletic trainer, athletic trainers have higher levels of job satisfaction.

At the secondary school level, athletic trainers are typically employed through school and/or districts as staff athletic trainers or through medical clinics as outreach athletic trainers.
Clinical outreach Athletic Trainers typically follow the medical model, reporting to a medical professional, typically a physician. This is increasing in popularity and being more heavily advocated to be followed in the collegiate setting but is still rare in the collegiate setting. Staff Secondary School Athletic Trainers are more closely related to their collegiate counterparts, following the collegiate model, which report to the Athletic Director or an administrator within the Athletic Department. This study on perception of their duties and job satisfaction can provide a glimpse into the comparison between the medical model and the athletics model.

As the only allied health care professional that is specifically trained to work with the physically active population with extensive training in emergent and non-emergent care, evaluation, and return to play guidelines, Athletic Trainers are significant in the safety of student athletes [1]. While athletes, athletic administrators, and parents may understand the value of the Athletic Trainer, the job descriptions may not be accurate in providing the Athletic Trainer the ability to perform to their best ability [2]. There have been studies based on the disparity of care between schools with high school Athletic Trainers and those without, as well as those receiving more funding, and whether they are private or public schools [3-6].

We focused primarily on finding if there were discrepancies in athletic trainer job descriptions, what additional duties they may have based on their positions, misconceptions in their capabilities, and affect job satisfaction.

\section{Participants}

Our participants consisted of certified athletic trainers employed in the secondary school setting across the United States. We contacted participants through links posted to social media pages for groups specifically catered toward secondary school athletic trainers. By clicking on the link and continuing to the survey, their consent was obtained. A total of 83 responses were collected, 67 of which self-identified as certified athletic trainers working in the secondary school setting.

\section{Procedure}

A recruitment post was posted on social media pages on various social media websites on groups dedicated to secondary school athletic trainers containing an informed consent. By choosing to continue to the survey, the participants consent was obtained. The survey conducted through Qualtrics to maintain confidentiality of the participants, with no personal identifiers collected. All the data collected was stored on Qualtrics under password encryption. 


\section{Instruments}

Due to the lack of previous studies and the nature of the study, we organized and edited a custom survey. The survey consisted of fourteen questions, eleven of which were demographical in nature, and three were perception-based questions on a modified Likert Scale ranging from Disagree, Disagree, Neutral, Agree, and Strongly Agree. The demographical questions pertaining to additional duties and employment status had options for free responses.

\section{Results}

Out of 83 responses, $67(80.7 \%)$ self-identified as certified athletic trainers working in the secondary school setting.

\begin{tabular}{|c|c|}
\hline Experience & N (\%) \\
\hline Years as a Certified Athletic Trainer \\
\hline Less than 1 year & $5(7.5 \%)$ \\
\hline 1-3 years & $13(19.4 \%)$ \\
\hline 4-6 years & $12(17.9 \%)$ \\
\hline 7-9 years & $9(13.4 \%)$ \\
\hline 10+ years & $28(41.8 \%)$ \\
\hline Years in the Secondary School Setting \\
\hline Less than 1 year & $6(9 \%)$ \\
\hline 1-3 years & $17(25.4 \%)$ \\
\hline 4-6 years & $16(23.9 \%)$ \\
\hline 7-9 years & $8(11.9 \%)$ \\
\hline 10+ years & $20(29.9 \%)$ \\
\hline
\end{tabular}

Table 1.1: Shows a breakdown of the experience of the participants.

Of the participants, the largest category is certified athletic trainers with over 10 years of experience at $41.8 \%$. A number having been certified for 1-3 years and 4-6 years, making up a selection of $19.4 \%$ and $17.9 \%$ respectively. Of the certified athletic trainers who have worked in the secondary school setting, there was no overwhelming selection but most selected $1-3$ years $(25.4 \%), 4-6$ years $(23.9 \%)$, and $10+$ years $(29.9 \%)$, making up $79.2 \%$ of participants.

\begin{tabular}{|c|c|}
\hline Employment & N (\%) \\
\hline \multicolumn{2}{|c|}{ Employment Status } \\
\hline Full Time & $55(83.3 \%)$ \\
\hline Part Time & $10(15.2 \%)$ \\
\hline Per-Diem & $1(1.5 \%)$ \\
\hline \multicolumn{2}{|c|}{ Hiring company } \\
\hline School/District & $34(50.7 \%)$ \\
\hline Outreach & $31(46.3 \%)$ \\
\hline Other & $2(3 \%)$ \\
\hline
\end{tabular}

Table 1.2: shows a breakdown of the employment of the athletic trainers, taking into account their classification and what entity had hired them. A vast majority of respondents $(83.3 \%)$ are full time athletic trainers at the secondary school setting, while the entities that hired the athletic trainers were relatively similar, with $50.7 \%$ hired through the school/district and $46.3 \%$ were at the high schools via outreach.

\begin{tabular}{|c|c|}
\hline Institutional Information & $\mathbf{n}(\%)$ \\
\hline \multicolumn{2}{|c|}{ Approximate number of student-athletes } \\
\hline Less than 100 & $1(1.5 \%)$ \\
\hline $100-200$ & $4(6.0 \%)$ \\
\hline $201-300$ & $12(17.9 \%)$ \\
\hline $301-400$ & $15(22.4 \%)$ \\
\hline $401-500$ & $8(11.9 \%)$ \\
\hline Over 500 & $27(40.3 \%)$ \\
\hline Number of Certified Athletic Trainers \\
\hline 2 & $41(62.1 \%)$ \\
\hline 3 & $21(31.8 \%)$ \\
\hline 4 or more & $3(4.5 \%)$ \\
\hline \multicolumn{2}{|c|}{} \\
\hline \multicolumn{2}{|c|}{}
\end{tabular}

Table 1.3 shows the institutional information for the schools.

A large number $(40.3 \%)$ of the schools have over 500 student athletes on campus, with the next largest grouping is approximately 301-400 student athletes at $22.4 \%$. A majority of the schools $(62.1 \%)$ have one certified athletic trainer onsite, with the next largest selection $(31.8 \%)$ is having two athletic trainers on site.

\begin{tabular}{|c|c|}
\hline Hours & n (\%) \\
\hline \multicolumn{2}{|c|}{ Expected hours at the secondary school } \\
\hline Less than 20 & $3(4.5 \%)$ \\
\hline $21-30$ & $12(17.9 \%)$ \\
\hline $31-39$ & $14(20.9 \%)$ \\
\hline $40+$ & $38(56.7 \%)$ \\
\hline Hours spent at the secondary school \\
\hline Less than 20 & $3(4.5 \%)$ \\
\hline $21-30$ & $7(10.4 \%)$ \\
\hline $31-39$ & $19(28.4 \%)$ \\
\hline $40+$ & $38(56.7 \%)$ \\
\hline
\end{tabular}

Table 1.4: shows the hours expected and the actual hours spent at the secondary school by the athletic trainers.

A majority of athletic trainers $(56.7 \%)$ are expected to spend over 40 hours at the secondary school, and the same numbers do spend that amount. While $17.9 \%$ of participants were expected to spend 21-30 hours at the secondary school, $10.4 \%$ of the participants noted they actually spent 21-30 hours. $20.9 \%$ of participants in the study were expected to spend 31-39 hours at the high school, but those who actually spent 31-39 hours at the high school were $28.4 \%$ of participants.

\begin{tabular}{|c|c|}
\hline Additional Duties & n (\%) \\
\hline & Position \\
\hline None & $34(49.28 \%)$ \\
\hline Teacher & $17(24.64 \%)$ \\
\hline $\begin{array}{c}\text { Healthcare } \\
\text { Administrator }\end{array}$ \\
\hline Nurse's Assistant & $1(2.9 \%)$ \\
\hline Medical Assistant & $2(2.9 \%)$ \\
\hline PT Aide/Technician & $4(5.8 \%)$ \\
\hline Other & $9(13.04 \%)$ \\
\hline
\end{tabular}

Table 2: shows the potential additional duties, participants had at the secondary school setting.

Participants were allowed to check multiple options and options that did not have responses were omitted from the table. Slightly less than majority (49.28\%) answered they had no other responsibilities outside of athletic training. Some (24.64\%) reported they were teachers in addition to their duties as athletic trainers. For the "other" category, participants responded duties at other medical facilities, taking on unofficial duties, or performing per-diem work. 


\begin{tabular}{|c|c|c|c|c|c|}
\hline \multicolumn{6}{|c|}{ Participants level of satisfaction and recognition } \\
\hline \multirow[b]{2}{*}{ Statement } & \multicolumn{5}{|c|}{ Agreement Level n (\%) } \\
\hline & Strongly Agree & Agree & Neutral & $\begin{array}{l}\text { Slightly } \\
\text { Disagree }\end{array}$ & Disagree \\
\hline 1. I am satisfied with my current job & $22(32.8 \%)$ & $34(50.7 \%)$ & $6(9 \%)$ & $4(6 \%)$ & $1(1.5 \%)$ \\
\hline $\begin{array}{l}\text { 2. My job description accurately captures the duties I } \\
\text { perform regularly }\end{array}$ & $19(28.4 \%)$ & $32(47.8 \%)$ & $7(10.4 \%)$ & $6(9 \%)$ & $3(4.5 \%)$ \\
\hline $\begin{array}{l}\text { I feel as is the staff, administration, and coaches } \\
\text { understand my capabilities and role on campus }\end{array}$ & $23(34.3 \%)$ & $27(40.3 \%)$ & $10(14.9 \%)$ & $4(6 \%)$ & $3(4.5 \%)$ \\
\hline
\end{tabular}

Table 3: Shows the participants level of satisfaction and how the associate perception they have with their duties.

Many athletic trainers fell within the agree section, $50.7 \%$, $47.8 \%$, and $40.3 \%$ respectively. The next largest section was strongly agree, with $32.8 \%, 28.4 \%$, and $34.3 \%$ respectively. A minority $(1.5 \%, 4.5 \%$, and $4.5 \%)$ disagreed with the statements concerning job satisfaction, the accuracy of their job description, and their coworkers understanding of their capabilities.

\section{Discussion}

The primary findings of our research found that there was a strong relationship between athletic trainers who were satisfied with their current jobs and those who felt that the staff, administration, students, and coaches understood the capabilities and role on campus. There was also a strong statistically significant relationship between athletic trainers who were satisfied with their current job and their job description accurately capturing the duties they perform regularly. Many of the participants in the study also had similar expectations in work hours to their actual work hours, which can explain the level of satisfaction. Using Qualtrics, there was no statistically significant relationship with the participants hours spent at the secondary school and their satisfaction. There was a statistically significant relationship between job satisfaction and length of time working in the secondary school setting, but not between job satisfaction and the length of time as a certified athletic trainer. A potential reason for this is that those who are in the secondary school setting typically work alone and are able to make the programs their own, providing some sense of ownership and freedom. This level of independence can provide some satisfaction, in particular to those who have begun their time in the secondary school setting, with $70.6 \%$ of participants who have been in the secondary school setting for 1-3 years. There was also a strong statistically significant relationship between those who believed their job description accurately captured their duties and those who felt the staff, administration, coaches, and students understood their capabilities and roles on campus. This further reinforces that the accuracy of job descriptions can allow the athletic trainer to perform their duties to the best of their ability, further promoting the profession of athletic training. Interestingly, there was no statistically significant relationship between the participant's employment status as staff or outreach athletic trainers and their satisfaction, accuracy of job description, and feeling understood.

\section{Further Research into Secondary School Athletic Trainer Satisfaction}

There needs to be further research into secondary school athletic trainer satisfaction and their job descriptions. In addition, there should be additional research into the collegiate and professional settings to see if there is any comparison. The field of athletic training is one where there can be a variety of expectations that can change from setting to setting, and a comparison between them may be worthwhile. This study was a brief glimpse into job descriptions for athletic training, there should also be additional research concerning the athletic trainers' direct supervisors, human resource management, and those around them to explore their understanding of athletic trainers and their capabilities.

\section{Conclusion}

Overall, it appears that athletic trainers in the secondary school setting who have had accurate job descriptions have high levels of job satisfaction. Individuals who had accurate hours expectations to their actual hours can be expected to have higher levels of satisfaction. The length of time as athletic trainers did not significantly affect athletic trainers but instead their time at the secondary school did affect satisfaction. This leads us to believe that with experience in the specific setting that an athletic trainer works in can provide a better predictor in their satisfaction than their experience overall.

\section{Limitations}

Limitations of this study were the short amount of questions and the number of respondents. There should be more variety to include more athletic trainers that are considered part-time and per-diem athletic trainers in the secondary school setting. There were also no free-response questions concerning their satisfaction and their job descriptions, in further research this can be expanded so that the reasoning behind those answers can explored. In further research, there should also be information collected based on where respondents are practicing in the nation, various states have different practice acts and the status of athletic training varies in recognition as a whole, some states with more significant athletic participation have a greater recognition of athletic trainers.

\section{References}

1. Huggins RA, Coleman KA, Attanasio SM, Cooper GL, Endres BD, et al. (2019). Athletic trainer services in the secondary school setting: the athletic training locations and services project. Journal of Athletic Training 54: 1129-1139.

2. Hootman JM (2009) 2008 Physical Activity Guidelines for Americans: an opportunity for athletic trainers. Journal of Athletic Training 44: 5-6.

3. Kroshus E, Rivara FP, Whitlock KB, Herring SA, Chrisman SP (2017) Disparities in athletic trainer staffing in secondary school sport: implications for concussion identification. Clinical Journal of Sport Medicine 27: 542-547.

4. Pike A, Pryor RR, Mazerolle SM, Stearns RL, Casa DJ (2016) Athletic trainer services in US private secondary schools. Journal of Athletic Training 51: 717-726.

5. Pike AM, Pryor RR, Vandermark LW, Mazerolle SM, Casa DJ (2017) Athletic trainer services in public and private secondary schools. Journal of Athletic Training 52: 5-11.

6. Athletic trainers: Occupational outlook handbook. (2020). Retrieved March 09, 2021, from https://www.bls.gov/ooh/healthcare/athletic-trainers.htm

Citation: Brown T, Ting RJ, Fiaud V (2021) Comparing Responsibilities between Outreach and Staff Secondary

School Athletic Trainers. Adv Ortho and Sprts Med: AOASM-141. 